\title{
Oregon State University's Integrated Pest Management Program for the Oregon Hazelnut Industry
}

\author{
J.L. Olsen
}

Additional Index words. Corylus avellana, orchard management, filbert, eastern filbert blight, IPM, pesticide use pattern, economic impact

Summary. Oregon State University (OSU) developed an integrated pest management (IPM) program for hazelnut (Corylus avellana.) in the early 1980s, through a USDA grant. Sampling schemes and action thresholds were refined over a period of 4 years for the filbertworm (Cydia latiferreana), filbert aphid (Myzocallis coryli), filbert leafroller (Archips rosanus.), and obliquebanded leafroller (Choristoneura rosaceana), which are the most important insect pests in Oregon hazelnuts. A classical biological approach was employed in the mid-1980s when the filbert aphid parasitoid, Trioxys pallidus, was imported from Europe. Grower survey results for 1981 and 1997 showed that the amount of pesticides applied for filbert aphid control has declined by $93 \%$. The registration of synthetic pyrethroids for filbertworm control and the use of pheromone trapping have reduced the amount of active ingredient applied in the industry by $96 \%$. The annual cost savings to Oregon hazelnut growers due to use of the OSU IPM program are estimated at $\mathbf{\$ 0 . 5}$ million. Current research focuses on the use of less toxic insecticides, such as insect growth regulators for filbertworm and leafroller control. The most serious hazelnut disease, eastern filbert blight (EFB) caused by the fungus Anisogramma anomala was first reported in the Pacific northwestern U.S. in 1973. It has spread its way through two thirds of the hazelnut acreage. Current OSU IPM recommendations include preventative fungicide sprays in spring, scouting for and cutting out infections, and replacement of the most susceptible cultivars when possible. The long-term approach to EFB control is the development of EFB immune varieties.

$\mathrm{O}$ regon's Willamette Valley accounts for about 99\% of the hazelnuts (also called filberts) grown in the U.S. Oregon's 30,000 acres $(12,141$ ha) represent about $5 \%$ of the world's hazelnut production. Oregon State University received a U.S. Department of Agriculture grant in 1982 to develop an IPM program in hazelnuts. The grant funded 4 years of research and development aimed at the establishment of sampling schemes and action thresholds for the main insect pests of hazelnut.

\section{Insect pests}

The four most important insect pests in hazelnut orchards in the Pacific northwestern U.S. are filbertworm, filbert aphid, filbert leafroller, and obliquebanded leafroller (AliNiazee, 1994). 
Table 1. Hazelnut integrated pest management sampling methods and action thresholds (O1sen et al., 2001 ).

\begin{tabular}{|c|c|c|}
\hline Insect & $\begin{array}{l}\text { Sampling } \\
\text { period }\end{array}$ & $\begin{array}{l}\text { Sampling } \\
\text { method }\end{array}$ \\
\hline European winter moth & Larvae: 15 Mar.-31 May & $\begin{array}{l}3 \text { terminals/tree and } 3 \text { leaf clusters/terminal. Each } \\
\text { terminal is a sampling unit. }\end{array}$ \\
\hline Filbert budmite & March-April & $\begin{array}{l}\text { By } 1 \text { Mar., place tanglefoot on twigs surrounding } \\
\text { blasted buds. Check for extremely small, white, cigar- } \\
\text { shaped mites with a } 20 \times \text { hand lens. }\end{array}$ \\
\hline Omnivorous leaftier & 15 Apr.-June & 3 bud clusters/tree \\
\hline Filbert aphid & 1 Apr.-30 Sept. & 3 terminals/tree, newest fully expanded leaf on each terminal \\
\hline \multicolumn{3}{|l|}{ Filbert leafroller and } \\
\hline \multirow[t]{2}{*}{ Obliquebanded leafroller } & Larvae: April-August & $\begin{array}{l}3 \text { terminals / tree and } 3 \text { leaf clusters/terminal. Each terminal is a } \\
\text { sampling unit. }\end{array}$ \\
\hline & Adult: mid-May-September & $\begin{array}{l}1 \text { pheromone trap for each } 5 \text { acres }(2.0 \text { ha }) \text {. Place in the tree } \\
\text { at a } 6 \mathrm{ft}(1.8 \mathrm{~m}) \text { height above the ground. }\end{array}$ \\
\hline Filbertworm & June-September & $\begin{array}{l}\text { Adult: pheromone traps- } 4 \text { for first } 10 \text { acres ( } 4.0 \text { ha) } \\
\text { and one for each additional } 4 \text { acres }(1.6 \text { ha). Place traps } \\
\text { in the upper } 1 / 3 \text { of the canopy by mid-June. }\end{array}$ \\
\hline
\end{tabular}

Table 2. Estimated costs to control hazelnut pests using the Consumer Price Index ratio of $469 / 247$ (1.9) to express 1980 costs as 1997 values. (Progar et al., 2000)

\begin{tabular}{|c|c|c|c|c|}
\hline $\begin{array}{l}\text { Insect } \\
\text { pest }\end{array}$ & $\begin{array}{l}\text { Estimated cost } \\
\text { to control } \\
\text { in } 1980 \\
(\$)\end{array}$ & $\begin{array}{c}1980 \\
\text { Value in } \\
1997 \\
(\$)\end{array}$ & $\begin{array}{l}\text { Estimated cost } \\
\text { to control } \\
\text { in } 1997 \\
(\$)\end{array}$ & $\begin{array}{c}\text { Estimated } \\
\text { change } \\
(\$)\end{array}$ \\
\hline Filbertworm & 560,783 & $1,065,488$ & $1,275,832$ & 210,344 \\
\hline Filbert leafroller & 212,490 & 403,731 & 274,190 & $-129,541$ \\
\hline Obliquebanded leafroller & 31,304 & 59,478 & 33,335 & $-26,143$ \\
\hline Filbert aphid & 323,374 & 614,411 & 48,666 & $-565,745$ \\
\hline Total & $1,127,951$ & $2,143,108$ & $1,632,023$ & $-511,085$ \\
\hline
\end{tabular}

The sampling schemes and action thresholds for all of the insect pests in hazelnuts are listed in Table 1 (Olsen et al., 2001). Also listed are european winter moth (Operophtera brumata), filbert budmites (Phytocoptella avellanae and Cecidophyopsis vermiformis), and omnivorous leaftier (Cnephasia longana). They cause only occasional damage and are considered minor pests in hazelnuts (AliNiazee, 1997).

Filbertworm is the most important of these insect pests. There is one generation per year that emerges in June through early October. A partial second generation occurs in some years. Hazelnut growers must keep the level of larval infestation at the time of harvest to below $1 \%$ to avoid extra handling charges. Pheromone traps are placed in the upper third of the canopy at a rate of four for the first 10 acres (4.0 ha) and one for each additional 4 acres (1.6 ha). Capture of two to three moths per trap or five moths in any one trap triggers the need for an insecticide treatment (Olsen et al., 2001). Growers average 1.5 sprays per season for filbertworm control. Prior to the mid-1980s, organophosphates and carbamates were the primary insecticides used to control filbertworm. Since the registration of synthetic pyrethroids in the mid-1980s, most growers have used esfenvalerate (Asana; E.I. duPont de Nemours and Co., Inc., Wilmington, Del.) for filbertworm control. Resistance to esfenvalerate has not yet occurred. The use of esfenvalerate at low rates of product per acre and pheromone trapping have reduced the amount of active ingredient of all insecticides applied for filbertworm control by the industry from 44 tons $(39.9 \mathrm{t})$ in 1981 , to 1.6 tons $(1.45 \mathrm{t})$ in 1997 . The pheromone trapping program also has helped to increase the accuracy of timing insecticide sprays.

Filbert APHID can cause a decline in plant vigor by feeding on its phloem reserves. If left unchecked this can re- duce yields. Filbert aphid had developed resistance to carbamates by the mid-1980s (Katundu and AliNiazee, 1990). A classical biological approach was employed in the mid-1980s when the filbert aphid parasitoid, Trioxys pallidus, was imported from European hazelnut orchards and released into Willamette Valley hazelnut orchards (Messing and AliNiazee, 1989). Trioxys pallidus proved to be well adapted to our hazelnut growing region and conditions, and spread naturally from its seed sites (AliNiazee and Messing, 1995 ). It can now be found in nearly all hazelnut orchards in Oregon and growers seldom have to spray for filbert aphid. Grower survey results show that the amount of pesticides applied for filbert aphid control has declined from 15,010 lb $(6,809 \mathrm{~kg})$ in 1981 , to $970 \mathrm{lb}(440$ $\mathrm{kg}$ ) in 1997 , with $92 \%$ of growers reporting reduced use(Progar etal.,2000).

Filbert LeAFroller AND obliquebanded leafroller (OBLR) 
When consistent mite movement is observed.

$5 \%$ infestation

April, 20 aphids/leaf

May, 30 aphids/leaf

June, 40 aphids/leaf

July, 40 aphids/leaf with an increasing population.

Larvae: 20\%-25\%; Adult: 40 moths/week and find larvae feeding on nuts.

2-3 moths/trap or 5 moths in any one trap

damage hazelnut by feeding on and rolling leaves in the spring. The OBLR has a second generation that can feed on nut clusters, causing them to drop. Through the early 1980s, most growers applied at least one insecticide every spring for combined aphid and leafroller control. With an action threshold of $20 \%$ to $25 \%$ leafroller larval infestation of either species, most orchards are now treated only about once every 4 years. Insecticide sprays for the filbert leafroller and the obliquebanded leafroller have been reduced (Progar et al., 2000). The reduction of early season insecticide applications for leafroller and filbert aphid management has had a positive effect, due to less disruption of the natural enemy complex.

\section{Diseases}

The most serious hazelnut disease in North America is eastern filbert blight. EFB was first reported in the Pacific northwestern U.S. in 1973 (Davidson and Davidson, 1973). Windblown spores infect the new vegetative growth of the tree in spring (Stone et al., 1992). The fungus moves into shoots and branches, with spore producing pustules forming a minimum of 15 months after the initial infection. The pustules are oval and distinctly raised above the bark surface. The disease moves through windblown spores and has spread its way through two thirds of the hazelnut acreage in Oregon. Current OSU IPM recommendations for growers include preventative fungicide sprays starting at bud break and repeating every 2 weeks, scouting for and cutting out infections, and replacement of the most susceptible cultivars when possible (Johnson et al., 1996). Growers currently spray one to three times at an estimated cost of about $\$ 35 /$ acre (\$86.48/ha). The long-term approach to the control of EFB is the development of EFB-immune cultivars. The OSU hazelnut breeding program has several promising resistant selections in advanced stages of testing.

\section{Conclusion}

Oregon hazelnut growers save about one half million dollars annually due to use of the OSU IPM program (Table 2). The current research in insect pest management focuses on the devel- opment of insect growth regulators for filbertworm and leafroller control. The release of EFB resistant cultivars will reduce the cost of producing hazelnuts for those new plantings.

\section{Literature cited}

AliNiazee, M.T. 1994. Insect pest management in hazelnut orchards of North America. Acta Hort. 351:543-549.

AliNiazee, M.T. and R.H. Messing. 1995. Filbert aphid, p. 123-129. In. J.R Nechols, L.A. Andres, J.W. Beardsley, R.D. Goeden, and C.G. Jackson (eds.). Biological control in the western United States. Univ. Calif., Div. Agr. Natural Resources, Publ. 3361.

AliNiazee, M.T. 1997. Integrated pest management of hazelnut pests: A worldwide perspective. Acta Hort. 445:469-476.

Davison, A.D. and R.M. Davidson, Jr. 1973. Apioporthe and Monochaetia canker reported in western Washington. Plant Dis. Rpt. 57:522-523.

Katundu, J.M. and M.T. AliNiazee. 1990. Variable resistance of filbert aphid (Homoptera: Aphididae) to insecticides in the Willamette Valley, Oregon. J. Econ. Entomol. 83:41-47.

Johnson, K.B., S.A. Mehlenbacher, J.K. Stone, J.W. Pscheidt, and J.N. Pinkerton. 1996. Eastern filbert blight of european hazelnut: It's becoming a manageable disease. Plant Dis. 80:1308-1316.

Messing R.H. and M.T. AliNiazee. 1989. Introduction and establishment of Trioxys pallidus in Oregon for the control of the filbert aphid. Entomophaga 34:153-163.

Olsen, J.L., G.C. Fisher, and J.W. Pscheidt, 2001. Pest management guide for hazelnuts in the Willamette Valley. Oregon State Univ. Ext. Bul. EM 8328.

Progar, R.A., M.T.AliNiazee, and J.L.Olsen. 2000. The economic and environmental impact of an IPM program on hazelnuts in Oregon. J. Entomol. Soc. B.C. 97:7-17.

Stone, J.K., K.B. Johnson, J.N. Pinkerton, and J.W. Pscheidt. 1992. Natural infection period and susceptibility of vegetative seedlings of european hazelnut to Anisogramma anomala. Plant Dis. 76:348-352. 